\title{
Households' Willingness To Pay And Associated Factors For The Nutrition Services Provided To Pregnant Women At Maternity Waiting Homes In East Wollega, Western Ethiopia
}

Adisu Ewunetu Desisa ( $\square$ adisuewunetu2019@gmail.com )

Institute of Health Science, Wollega University https://orcid.org/0000-0003-4465-6629

Teferi Daba Lemma

Institute of Health Science, Wollega University

Gebeyehu Jeldu chali

Institute of Health Science, Wollega University

\section{Research}

Keywords: access to care, housing facility, Willingness to pay, associated factors

Posted Date: August 24th, 2021

DOl: https://doi.org/10.21203/rs.3.rs-809091/v1

License: (c) (i) This work is licensed under a Creative Commons Attribution 4.0 International License.

Read Full License 


\section{Abstract}

Background: Maternity waiting home is a housing facility located near qualified medical facilities where a pregnant woman can wait to give birth and provided a nutrition service. In Ethiopia, most (86\%) of the maternity waiting homes had no budget allocated from government funds and thus have to rely on communities' contribution. Yet, very few studies have been conducted so far to evaluate the household's willingness to pay for the nutrition service.

Objective: The study aimed to estimate households' maximum willingness to pay and its associated factors for the nutrition service provided to a pregnant woman at a maternity waiting homes in East Wollega Zone of Oromia National regional state, Ethiopia, September 2018.

Methodology: A community based cross sectional study using double bounded dichotomous choice contingent valuation method was used. Sample size was determined by using single population proportion formula. Data entry and analysis were made using Epi-Data version 3.1 and SPSS for Windows version 20 software respectively. Descriptive statistics of frequency, binary and multivariable logistic regression analysis were performed. The associations between explanatory variables and outcome variable were presented by an Adjusted Odd Ratio and confidence interval.

Results: We gathered data from 845 participants ( $98 \%$ response rate). The annual median maximum willingness to pay was 15ETB (US\$0.55) per household. Marital status (AOR=3.533, 95\% Cl=1.007-12.39) and average monthly income ( $\mathrm{AOR}=3.287,95 \% \mathrm{Cl}=1.194-9.049)$. Moreover, distance from the health facility $(A O R=3.64,95 \% \mathrm{Cl}=1.256-10.55)$ and availability of food (AOR=3.714, 95\%Cl=1.331-10.364), enough beddings $(A O R=5.353,95 \% \mathrm{Cl}=2.207-13.010)$ and cooking utensils $(A O R=4.044,95 \% \mathrm{Cl}=1.353-$ 12.088 ) at a housing facility were found to be predictors.

Conclusion and Recommendation: Marital status, monthly income, and distance, availability of food, beddings and cooking utensils at housing facilities were found to be factors influencing maximum willingness to pay. Therefore, health facility managers should avail supplies and equipment at a housing facility.

\section{Introduction}

Pregnancy is a crucial time to promote healthy behaviors. Inadequate care during this time breaks a critical link in the continuum of care, and affects both women and babies. Good care during this time is important for the health of the mother and the development of the unborn baby. Antenatal care (ANC) and postnatal care (PNC) is a key strategy to improve maternal and infant health(1-3).

The chances of women dying as a result of complications during pregnancy, delivery or the postpartum period remain high in many parts of the world. Lack of access to obstetric services is one of the main causes of the high incidence of maternal and newborn deaths. In many rural, and poor districts of subSaharan Africa; maternal mortality is high and utilization of maternal health services is low. A study done 
in some parts of Ethiopia showed that maternal mortality and home delivery is still high. Long distances, poor transport facilities and inadequate distribution of health care facilities are responsible for low utilization of health care services in many rural districts in low-income countries (3-5).

Access to comprehensive emergency obstetric care is limited in Ethiopia. Maternity waiting homes are part of the strategies utilized to improve access the hard to reach rural populations. In Ethiopia, the practice of nutrition services provision at maternity waiting home has not been adequately assessed so far. It can be one approach to improve access to comprehensive emergency obstetric care for rural mothers in Ethiopia who are challenged by distance to access services(5-7).

Maternity waiting homes (shelters) are residential facilities located near qualified medical facilities where pregnant woman can wait to give birth. The shelters could play a key role in helping ensure access to comprehensive maternity care, provided communities are willing to help sustain them. The aim of the MWH (Maternal waiting home) is to improve accessibility and thus reduce morbidity and mortality for mother and neonate should complications arise $(4,7)$.

Active community involvement and quality care within the health care facility are key to the use and sustainability of a MWH. To improve sustainability of these communities owned and managed shelters; Contributions, either in the form of individual donations or an annual community contribution, have potential to support the long-term financial sustainability of the shelters. To be successful, maternity waiting homes should have community involvement and support(8-10).

Financing health care is a sensitive issue that is currently being discussed around the world. The quality of health services provided and increasing in the health care cost is the main concerns related to this. In many developing countries; people are expected to contribute to the cost of health care from their own resources. But, the amount that an individual is willingness to pay may or may not be adequate for the sustainability of a given healthcare and have many influencing factors (11). In developing countries lack of adequate health care budgets is a severe problem. Traditional ways such as raising health care tariffs is not an adequate response to the increasing costs of health care. Lower income groups such as rural residents, unlike medium and higher income groups, may reduce the amount they are willing to pay and are more sensitive to price changes in health care services (7)

Thus advanced ways to raise funds for the provision of health services are often sought. However, a rural households' willingness to pay for health care services and if so, how much and what factors determine their willingness to pay for the sustainability of the health care services are still not well known. The need for, and willingness to pay (WTP) for, health care services varies between areas. Average households' willingness to pay may match or exceed the cost of their health care(8).

In Ethiopia, many MWHs were built with the support of the community, which usually contribute money for the services provided to mothers staying at these waiting homes. Funding is required to lower other barriers to utilization, such as food provision. Most (86\%) of the MWHs had no budget allocated from 
government funds and there is a shortage of revenue for the long term sustainability of the MWH services $(11-13)$.

Households' contribution is mandatory to improve sustainability of this community- owned and managed shelters; but it is unknown how much they might be willing to contribute and what factors determines their willingness to pay for the services to use community-managed shelters. Determining the recurrent cost for a renovating the shelter to provide food and to assess this cost in relation to willingness to pay is important. There are also women who give birth at home because of lack of affordability for the suggested donation at the maternity waiting home service $(4,6,9,11)$.

In addition studies conducted in different parts of Ethiopia showed that there is a shortage of food availability, kitchen utensils and fuel as well as lack of basic social and healthcare services such as; inadequate beddings, water and sanitary services, lack of visits to mothers staying at a MWH were the factors deterring the use of MWHs were some of the barriers to access and utilization of a MWH $(6,12$, 13).

Currently, majority of the maternity waiting homes are located in rural health centers serving about 8-12 pregnant woman at a time and annually each household is expected to voluntarily contribute money to the nutrition service provided to pregnant mothers staying at maternity waiting home. Pregnant woman will come and stay at a MWH one-two weeks before the current amount of price proposed by the government to be paid annually was 10 ETB per household. This is because there is a difference in the amount of money contributed from area to area or region to region. Though the amount of price to be paid was proposed by the government, it was being paid by the households annually. But there were no a settled tariff for how much should households has to contribute in an average for the service as a result; the level of household participation and the revenue generated so far is unsatisfactory. There were a very few study conducted on the households' willingness to pay for this service and factors affecting the households' WTP for the services were not identified.

This study is, therefore, meant to identify critical factors that determine household's MWTP (maximum willingness to pay) for the nutrition service provided to a pregnant woman at a $\mathrm{MWH}$ and estimate the maximum amount of households' WTP per year for the nutrition services provided to the pregnant women staying at a MWH. In addition, it is aimed to identify the households' attitude and support towards the nutrition service provided to pregnant women at MWHs.

\section{Methods And Materials}

\section{Study area and period}

This study was conducted from August 13-September 02/2018 in the East Wollega zone of Oromia Regional State, Ethiopia. Ethiopia is a federation subdivided into ethno-linguistically based on regional states and chartered cities. Regions are each governed by a reginal council whose members are directly elected to represent woreda while zones are a second level of subdivision of Ethiopia below regions and 
above woredas or districts. Districts or woredas are the third-level administrative divisions of Ethiopia and they are further subdivided into a number of kebeles which are the smallest unit of local government in Ethiopia. There are about 12 regions and more than 68 zones in Ethiopia. The East Wollega Zone is one of the zones in Oromia region and its Town is Nekemte. It is located $333 \mathrm{~km}$ from Addis Ababa and has 17 woredas and has a total population of $1,535,415$. The zone has 225,599 total numbers of households and it has a total of 59 health centers, 189 primary clinics, and 05 medium clinics. The zone has seventeen (17) rural and forty seven (47) urban drug stores. In Ethiopia, majority of the maternity waiting homes are being built at woreda level and in primary health facilities under the woredas. In the zone eleven woredas have maternity waiting homes, but all the households in the zone pay for the nutrition services provided to the pregnant mothers. The zone has a total of three hundred fifteen(315) kebeles and there are one hundred sixty two(162) kebeles in the nine (9) randomly selected woredas(14).

\section{Study design and source population}

Community based cross sectional study design was employed. The study population was all households in Eastern Wollega Zone but household heads that lived in that area for at least one year were included in the study. In addition, a household heads those who have under-five children and whose mothers who have previously history of giving birth at health facility were interviewed. Household heads that was seriously and mentally ill was excluded from the study because it is the responsibility of heads' of the households to pay for the services annually and possibly respond for the questions.

\section{Sample size and Sampling procedures}

The sample size was determined by using single population proportion formula. Since no study was conducted on the issue in the study area, the sample size was calculated by assuming the half of the households are willing to pay for the nutrition service provided to a pregnant women ( $P=50 \%)$ and $95 \%$ confidence interval $(Z=1.96)$ with a margin of error $(d=0.05)(15)$.

Therefore, by inserting the values in the following formula: $n=\left(Z_{x / 2}\right)^{2} p(1-p) / d^{2} ;$ where: $Z_{a / 2}$ is a standard score value for $95 \%$ confidence level for two sides normal distribution, $\mathbf{P}=(50 \%)$ whereas $\mathbf{d}=$ is margin of error which is equal to $5 \%$ and $\mathbf{n}$ is the maximum possible sample size. Given these assumptions the sample size was estimated to be $\mathbf{3 8 4}$. By multiplying it with the design effect of two (2) and adding $\mathbf{1 0 \%}$ for potential non-response, the final sample size became $\mathbf{8 4 5}$.

Following WHO assessment guideline, out of seventeen (17) woredas in the East wollega zone $\mathbf{5 0} \%$ ( 9 ) of the woredas were selected. Similarly out of three hundred fifteen (315) kebeles in the zone $10 \%$ (32) of the kebeles were selected.(16) These nine (9) woredas and thirty two (32) kebeles were selected randomly by using a lottery method. The required numbers of kebeles were proportionately allocated to their respective woredas and the required numbers of households were proportionately allocated to their respective kebeles. 
The following formula was used to proportionally allocate the number of kebeles to each woredas as well as households to each kebeles: $\mathbf{n}_{\mathrm{i}}=\mathrm{nN}_{\mathrm{i}} / \mathbf{N}$ where; $\mathrm{n}_{\mathrm{i}}$ =the sample size of the $\mathrm{i}^{\text {th }}$ kebele, $\mathrm{n}=$ sample size, $\mathrm{N}_{\mathrm{i}}=$ population size of the $\mathrm{i}^{\text {th }}$ kebele and $\mathrm{N}=$ the total population of the catchment area. Finally; the households were randomly selected by a lottery method using the family folder (a registration containing the name of members each household) at the health posts as a sampling frame (Table 1).

Table 1: Sampling procedures of the study areas and the study participants in East wollega Zone, Oromia regional state, Ethiopia, September 2018.

\begin{tabular}{|c|c|c|c|c|c|c|c|c|c|c|}
\hline $\begin{array}{l}\text { Name of randomly } \\
\text { selected woredas }\end{array}$ & 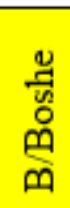 & 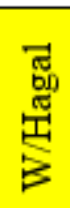 & 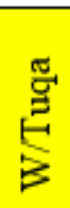 & 总 & 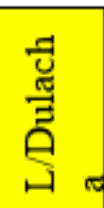 & 量 & 莺 & 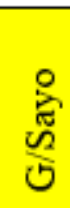 & 哭 & Total \\
\hline $\begin{array}{l}\text { Proportionally allocated } \\
\text { numbers of kebeles }\end{array}$ & 3 & 3 & 3 & 3 & 4 & 4 & 4 & 4 & 4 & \\
\hline $\begin{array}{l}\text { Proportionally allocated } \\
\text { numbers of households }\end{array}$ & 65 & 83 & 82 & 132 & 77 & 149 & 105 & 69 & 83 & \\
\hline
\end{tabular}

\section{Data collection tools and techniques}

To elicit the respondents' maximum willingness to pay both close ended and open ended double bounded dichotomous (DBDC) contingent valuation techniques were used. Data was collected by using face-toface interviewer administered questionnaire. Four point likert scale questions were designed to elicit the respondent's attitude towards the problem as well as towards the importance of the service. In addition a dichotomous questions to identify their support towards the nutrition services provided to pregnant women staying at a maternity waiting home and willingness to pay questions to elicit the respondents' stated preference for the improvement of the service (17).

The bidding game was offered for the respondents to know their willingness to pay. Hence, the initial bidding price used was the currently paid price (10ETB) that was proposed by the government to be paid by households for the nutrition services provided to a pregnant woman staying at a maternity waiting home annually. Then 2ETB was used to add and subtract from the initial bidding price depending on respondents' response to the initial bidding price (10ETB). As a result, if the respondents were willing to pay more when asked to pay additional price, 2ETB was added on initial bidding price up to two incremental stages (10ETB, 12ETB, 14ETB) then WTP Max was asked. But if the respondents were not willing to pay the initial bidding price, then 2ETB was used to subtract from the initial bidding price for those who were not willing to pay the initial price up to two detrimental stages(10ETB,8ETB,6ETB) then WTP max was asked.

The bidding game was conducted as follows: First, the price currently proposed by the government (10ETB) was used as initial bidding price. For the respondent who accepted the initial bidding price (willing to pay 10ETB), the bid was raised to 12 ETB by adding 2 ETB on the initial bidding price. If he or 
she again accepted this amount (12ETB), then the bid was raised to 14 ETB by adding 2ETB on 12ETB and then respondents were asked their willingness to pay this amount of price. At this level the respondent was asked about his/her maximum WTP either if he or she accepted or rejected the 14 ETB bid. In a similar way, if the respondent rejected the starting bid 10 ETB, the bid was lowered to 8 ETB by reducing $2 \mathrm{ETB}$ from the initial bidding price. A respondent who accepted this bid was asked about her or his WTP max. But for a respondent, who rejected 8ETB, the bid was lowered to 6 ETB and then the respondent was asked about his or her maximum WTP (Fig: 1).

\section{Study variables}

Dependent variable: Amount of willingness to pay

Independent Variables include

- Socio demographic factors such as: - Age, Marital status, Sex, Educational status, Occupation, Distance from the health facility, and Family size.

- Socio economic factors such as:-Income, Affordability and Decision on money spending.

- Basic social and healthcare services factors such as:- service quality provided to a pregnant woman staying at a MWH, Satisfaction gained from the nutrition services provided at a $\mathrm{MWH}$, Privacy at a $\mathrm{MWH}$, Availability of sanitary services, Availability of food, Availability of (water, beddings, cooking facilities, power or electricity), and Lack of visits to mothers at MWH.

- Influences of other individuals such as; Effect of peers, cooperation b/n Healthcare providers and pregnant women, and Perception about who should pay for the service

Data were entered using Epi-Data version 3.1 and analyzed using SPSS for windows version 20 software. Frequency distribution of dependent and independent variables were performed. Bivariate analysis was carried out to determine associations of selected variables with dependent variable and p-value of less than or equal to 0.25 was taken as a cutoff point to consider a variable as candidate for the final multiple logistic regression. Independent predictors were determined using adjusted odds ratio with $95 \%$ confidence interval in a multiple regression analysis.

\section{Data quality assurance}

Due care was made to assure the quality of the data. Training was given for data collectors and supervisors on data collection tools. The tools were translated to local language (Afan Oromo) and were pre-tested. The completeness of the questionnaire at the end of the day was checked by supervisors on field and rechecked by the principal investigator.

Ethical Approvalwas taken from JU Health Institute, Faculty of Public Health. Responses of respondents' were anonymous and data collectors were informed respondents that they have full right to discontinue or refuse to participate in the study if they were not willing to participate. 


\section{Results}

\section{Socio demographic characteristics of the respondents}

A total of $\mathbf{8 4 5}$ households in the East wollega zone were included in the study of which $\mathbf{8 3 0}$ responded, making the response rate (98\%). More than half of the respondents (54.7\%) were young female household heads with the mean of the age of 30.58 years ( $S D \pm 8.6)$. Christianity is the dominant religion in the area (54.5\% of the respondents were Protestants, and $33.2 \%$ were Orthodox). Furthermore, about $92.7 \%$ of them were ethnic Oromos and the remaining (7.3\%) were Amharas.

Majority of the participants $83.7 \%$ were married and the average households' family size was 5.07 (SD \pm 1.95). This is higher than the national average household size (4.6) and even higher than national rural household size (4.9). Like many rural household heads, majority $(38.6 \%)$ of the respondents were unable to read and write and the other $37.83 \%$ of them has elementary $(1-8)$ school education More than half of the respondents $(58.1 \%)$ were farmers whereas only $9.64 \%$ were government employees. The median monthly income of the respondents was 600 ETB and the mean distance of the health facility from the households was 4.6(SD \pm 2.58 ) (Table 2). 
Table 2

Socio-demographic characteristic of the respondents in East Wollega Zone, Oromia regional sate, Ethiopia, 2018

\begin{tabular}{|c|c|c|c|}
\hline \multirow[t]{2}{*}{ Variables } & \multicolumn{2}{|c|}{ WTP for the nutrition service } & \multirow[t]{2}{*}{ Tota } \\
\hline & WTP < 10 ETB & WTP $>=10 \mathrm{ETB}$ & \\
\hline \multicolumn{4}{|l|}{ Sex } \\
\hline Male & $17(36.2)$ & $359(45.8)$ & 376 \\
\hline Female & $30(63.8)$ & $424(54.2)$ & 454 \\
\hline \multicolumn{4}{|l|}{ Age } \\
\hline $18-24$ years & 19(40.4) & $159(20.3)$ & 178 \\
\hline $25-34$ years & $15(31.9)$ & $392(50.1)$ & 407 \\
\hline $35-44$ years & $4(8.5)$ & $190(24.3)$ & 194 \\
\hline 45 years and above & $9(19.1)$ & $42(5.4)$ & 51 \\
\hline \multicolumn{4}{|l|}{ Marital status } \\
\hline Married & $34(72.3)$ & $661(84.4)$ & 695 \\
\hline Single & 13(27.7) & $122(15.6)$ & 135 \\
\hline \multicolumn{4}{|l|}{ Ethnicity } \\
\hline Oromo & $43(91.5)$ & 726(92.7) & 769 \\
\hline Amhara & $4(8.5)$ & $57(7.3)$ & 61 \\
\hline \multicolumn{4}{|l|}{ Religion } \\
\hline Orthodox & 17(36.2) & $253(32.3)$ & 270 \\
\hline Muslim & $9(19.1)$ & $99(12.6)$ & 108 \\
\hline Protestant & $21(44.7)$ & $431(55)$ & 452 \\
\hline \multicolumn{4}{|l|}{ Educational status } \\
\hline Illiterate & $30(63.8)$ & $290(37)$ & 320 \\
\hline Can read and write & $7(14.9)$ & $70(8.9)$ & 77 \\
\hline Elementary $(1-8)$ & $9(19.1)$ & $305(39)$ & 314 \\
\hline Secondary(9-12) & $0(0)$ & 78(10) & 78 \\
\hline College and above & $1(2.1)$ & $40(5.1)$ & 41 \\
\hline
\end{tabular}




\begin{tabular}{|c|c|c|c|}
\hline \multirow[t]{2}{*}{ Variables } & \multicolumn{2}{|c|}{ WTP for the nutrition service } & \multirow[t]{2}{*}{ Total } \\
\hline & WTP $<10$ ETB & WTP $>=10 \mathrm{ETB}$ & \\
\hline \multicolumn{4}{|l|}{ Occupational status } \\
\hline Farmer & $23(48.9)$ & $459(58.6)$ & 482 \\
\hline Student & $0(0)$ & $9(1.1)$ & 9 \\
\hline House wife & 15(31.9) & $116(14.8)$ & 131 \\
\hline Government Employer & $2(4.3)$ & $78(10)$ & 80 \\
\hline Merchant & $0(0)$ & 79(10.1) & 79 \\
\hline Daily laborer & $7(14.9)$ & $42(5.4)$ & 49 \\
\hline \multicolumn{4}{|l|}{ Average monthly income } \\
\hline Less than 200 ETB & $7(14.9)$ & $92(11.7)$ & 99 \\
\hline $200-400$ ETB & 13(27.7) & $149(19)$ & 162 \\
\hline 401-692 ETB & 18(38.3) & 191(24.4) & 209 \\
\hline Greater than 692 ETB & $9(19.1)$ & $351(44.8)$ & 360 \\
\hline \multicolumn{4}{|c|}{ Distance of the HHs from the health facility } \\
\hline Less than $5 \mathrm{KM}$ & $40(85.1)$ & $553(70.6)$ & 593 \\
\hline Greater or equal to $5 \mathrm{~km}$ & $7(14.9)$ & $230(29.4)$ & 237 \\
\hline
\end{tabular}

Households' WTP for the nutrition service at MWH

Among 830 respondents, 783 (94.3\%) were willing to pay greater or equal to 10 ETB whereas only 47 (5.7\%) were willing to pay less than 10 ETB with a minimum of 5ETB and maximum of 8ETB for the nutrition service provided to a pregnant women at $\mathrm{MWH}$.

The average maximum amount of respondents' willingness to pay for the nutrition provided to a pregnant women staying at MWH was found to be 15 ETB ( 0.55 USD) per year per household. This is $50 \%$ higher than the prevailing price set by the government. The minimum WTP for the service was 5ETB and maximum was 500 ETB. The proportion of respondents who were willing to pay below the median maximum amount (15ETB) was about $45.2 \%$, whereas about the proportion of respondents who were willing to pay above the median maximum amount were $43.1 \%$. About $5.7 \%$ of the respondents were willing to pay below 10 ETB while $51.2 \%$ of the respondents were willing to pay between 10 ETB and 15 ETB. (Table 3 and Fig. 2) 
The Fig. 2 shows that the large majority of the household heads are willing to pay more than the prevailing price $(10 \mathrm{br})$. Only six percent of them were willing to pay less than $10 \mathrm{Br}$. This may be due to the fact that female headed households constitute significant proportion of the respondents. Table 3 summarizes the respondents' maximum willingness to pay for the nutrition service provided to a pregnant woman at MWH per year per household.

Table 3

Summary of annual maximum willingness to pay for the nutrition service provided to a pregnant women at MWH

\begin{tabular}{|llll|}
\hline \multirow{2}{*}{ Variables } & \multicolumn{3}{l|}{ Maximum WTP for the nutrition service } \\
\cline { 2 - 4 } & Minim (ETB) & Maximum(ETB) & Median (ETB) \\
\hline Less than 10 ETB & 5 & 8 & 8 \\
\hline Between 10 and 15 ETB & 10 & 15 & 10 \\
\hline Above 15 ETB & 16 & 500 & 20 \\
\hline
\end{tabular}

\section{Determinants of Households willingness to pay for the nutrition service}

Logistic regression analysis was used to identify the major explanatory variables of households' the maximum willingness to pay for the nutrition service provided to a pregnant women staying at a $\mathrm{MWH}$. It was revealed that age of the respondent was one major determinant as younger households are more likely to be willing to pay for the nutrition service provided to a pregnant woman at a MWH. For instance, it was noted that the MWTP of a group of respondents who had a mean age of 52.78 years (SD \pm 8.09$)$ were nearly $94 \%$ lower than the MWTP of a group who had a mean age 28.42 years (SD \pm 2.56 ). On the other hand, respondents who were ever married had higher willingness to pay $(\mathrm{AOR}=3.533,95 \% \mathrm{Cl}=$ 1.007-12.39) than unmarried counterparts.

Surprisingly, respondents collage and above educated respondents had lower willingness to pay for the nutrition service $(A O R=0.346,95 \% \mathrm{Cl}=0.14-0.857)$ compared to illiterate counterparts. Respondents who were house wife $(A O R=2.625,95 \% \mathrm{Cl}=1.075-6.413)$ and daily laborers $(A O R=3.593,95 \% \mathrm{Cl}=1.068-$ 12.089) had higher willingness to pay than farmers. Respondents who had a median monthly income of 1000ETB ( $A O R=3.287,95 \% \mathrm{Cl}=1.194-9.049$ ) were more likely to have higher WTP for the service as compared respondents who had a median monthly income of 100 ETB.

Respondents who were closer to the health facility (at less than $5 \mathrm{~km})(\mathrm{AOR}=3.64,95 \% \mathrm{Cl}=1.256-10.55)$ had higher willingness to pay for the nutrition service than those who were living at distant (at greater than $5 \mathrm{~km}$ ) from the health facility. Furthermore, WTP was positively influenced by respondents perception/believe in the availability of quality food $(\mathrm{AOR}=3.714,95 \% \mathrm{Cl}=1.331-10.364)$, beddings $(A O R=5.353,95 \% \mathrm{Cl}=2.207-13.010)$ and cooking facilities $(A O R=4.044,95 \% \mathrm{Cl}=1.353-12.088)$ at a $\mathrm{MWH}$. 
Respondents had a higher willingness to pay if someone else was paying ( $A O R=2.691,95 \% \mathrm{Cl}=1.204-$ 6.011) and respondents had a higher willingness to pay if they believed that it was not the government's responsibility to pay for the nutrition services provided to a pregnant woman at a maternity waiting home $(\mathrm{AOR}=3.643,95 \% \mathrm{Cl}=1.669-7.948)$ than others.

Adequacy and fitness of model were checked (with Naskerkele R square of $45 \%$ and Hosmer Lemeshow of $p$-value $>0.06$ ). (Table 4) 
Table 4

Predictors of WTP for the nutrition provided to a pregnant women at a MWH in East Wollega Zone, Oromia regional state, Ethiopia, September 2018.

\begin{tabular}{|c|c|c|c|c|}
\hline \multirow[t]{3}{*}{ Variables } & \multicolumn{2}{|c|}{$\begin{array}{l}\text { WTP for the nutrition } \\
\text { service }\end{array}$} & \multicolumn{2}{|l|}{ OR and $95 \% \mathrm{Cl}$} \\
\hline & $<10 \mathrm{ETB}$ & $>=10 \mathrm{ETB}$ & $\operatorname{coR}(95 \% \mathrm{Cl})$ & AOR(95\%Cl) \\
\hline & $\begin{array}{l}n= \\
47(\%)\end{array}$ & $\begin{array}{l}n= \\
783(\%)\end{array}$ & & \\
\hline \multicolumn{5}{|l|}{ Age } \\
\hline $18-24$ years & 19(40.4) & 159(20.3) & 1 & \\
\hline $25-34$ years & 15(31.9) & $392(50.1)$ & $\begin{array}{l}0.558(0.235- \\
1.322)\end{array}$ & $\begin{array}{l}0.368(0.115- \\
1.74)\end{array}$ \\
\hline $35-44$ years & $4(8.5)$ & $190(24.3)$ & $\begin{array}{l}0.179(0.074- \\
0.433)\end{array}$ & $\begin{array}{l}0.09(0.027- \\
0.3)^{\star \star \star}\end{array}$ \\
\hline 45 years and above & $9(19.1)$ & $42(5.4)$ & $\begin{array}{l}0.098(0.029- \\
0.334)\end{array}$ & $\begin{array}{l}0.06(0.013- \\
0.25)^{\star \star \star}\end{array}$ \\
\hline \multicolumn{5}{|l|}{ Marital status } \\
\hline Never married & 13(27.7) & $122(15.6)$ & 1 & \\
\hline Ever married & $34(72.3)$ & $661(84.4)$ & $\begin{array}{l}2.072(1.036- \\
4.039)\end{array}$ & $\begin{array}{l}3.53(1.007- \\
12.39)^{\star}\end{array}$ \\
\hline \multicolumn{5}{|l|}{ Educational status } \\
\hline Illiterate & $30(63.8)$ & $290(37)$ & 1 & \\
\hline Can read and write & $7(14.9)$ & $70(8.9)$ & $\begin{array}{l}0.273(0.185- \\
0.623)\end{array}$ & $\begin{array}{l}0.510(0.167- \\
1.554)\end{array}$ \\
\hline Elementary (1-8) & $9(19.1)$ & $305(39)$ & $\begin{array}{l}0.285(0.133- \\
0.611)\end{array}$ & $\begin{array}{l}0.108(0.004- \\
2.945)\end{array}$ \\
\hline Secondary $(9-12)$ & $0(0)$ & $78(10)$ & $\begin{array}{l}0.351(0.132- \\
0.597)\end{array}$ & $\begin{array}{l}0.284(0.175- \\
1.05)\end{array}$ \\
\hline College and above & $1(2.1)$ & $40(5.1)$ & $\begin{array}{l}0.242(0.032- \\
1.82)\end{array}$ & $\begin{array}{l}0.346(0.140- \\
0.86)^{\star}\end{array}$ \\
\hline \multicolumn{5}{|l|}{ Occupational status } \\
\hline Farmer & $23(48.9)$ & $459(58.6)$ & 1 & \\
\hline House wife & 15(31.9) & $116(14.8)$ & $\begin{array}{l}2.581(1.305- \\
5.102)\end{array}$ & $\begin{array}{l}2.63(1.08- \\
6.4)^{*}\end{array}$ \\
\hline
\end{tabular}

${ }^{*} p$-value $<0.05,{ }^{* \star *} p$-value $<0.001,1=$ reference 


\begin{tabular}{|c|c|c|c|c|c|}
\hline \multirow[t]{3}{*}{ Variables } & & \multicolumn{2}{|c|}{$\begin{array}{l}\text { WTP for the nutrition } \\
\text { service }\end{array}$} & \multicolumn{2}{|l|}{ OR and $95 \% \mathrm{Cl}$} \\
\hline & & \multirow{2}{*}{$\begin{array}{l}<10 \text { ETB } \\
n= \\
47(\%)\end{array}$} & \multirow{2}{*}{$\begin{array}{l}>=10 E T B \\
n= \\
783(\%)\end{array}$} & \multirow[t]{2}{*}{$\operatorname{COR}(95 \% \mathrm{Cl})$} & \multirow[t]{2}{*}{$\operatorname{AOR}(95 \% \mathrm{Cl})$} \\
\hline & & & & & \\
\hline Daily laborer & & $7(14.9)$ & $42(5.4)$ & $\begin{array}{l}3.33(1.35- \\
8.21)\end{array}$ & $\begin{array}{l}3.59(1.1- \\
12.1)^{\star}\end{array}$ \\
\hline \multicolumn{6}{|l|}{ Average monthly income } \\
\hline \multicolumn{2}{|l|}{ Less than 200 ETB } & $7(14.9)$ & $92(11.7)$ & \multicolumn{2}{|l|}{1} \\
\hline \multicolumn{2}{|l|}{$200-400$ ETB } & 13(27.7) & 149(19) & $\begin{array}{l}2.967(1.076- \\
8.18)\end{array}$ & $\begin{array}{l}1.307(0.34- \\
5.020)\end{array}$ \\
\hline \multicolumn{2}{|l|}{ 401-692 ETB } & 18(38.3) & 191(24.4) & $\begin{array}{l}3.403(1.424- \\
8.132)\end{array}$ & $\begin{array}{l}2.55(0.828- \\
7.863)\end{array}$ \\
\hline \multicolumn{2}{|l|}{ Greater than 692 ETB } & $9(19.1)$ & $351(44.8)$ & $\begin{array}{l}3.675(1.62- \\
8.339)\end{array}$ & $\begin{array}{l}3.29(1.194- \\
9.049)^{*}\end{array}$ \\
\hline \multicolumn{6}{|c|}{ Distance of the $\mathrm{HH}$ from the health facility } \\
\hline \multicolumn{2}{|l|}{ Less than $5 \mathrm{KM}$} & $40(85.1)$ & $553(70.6)$ & $\begin{array}{l}2.377(1.049- \\
5.383)\end{array}$ & $\begin{array}{l}3.6(1.256- \\
10.557)^{*}\end{array}$ \\
\hline \multicolumn{2}{|l|}{ Greater or equal to $5 \mathrm{KM}$} & $7(14.9)$ & $230(29.4)$ & \multicolumn{2}{|l|}{1.00} \\
\hline \multirow[t]{2}{*}{ Availability of food at a MWH } & Yes & $40(85.1)$ & $533(68.1)$ & $\begin{array}{l}2.68(1.184- \\
6.067)\end{array}$ & $\begin{array}{l}\text { 3.7(1.331- } \\
10.364)^{*}\end{array}$ \\
\hline & No & $7(14.9)$ & $250(31.9)$ & 1.00 & \\
\hline \multirow[t]{2}{*}{ Availability of water at a MWH } & Yes & $41(87.2)$ & $570(72.8)$ & $\begin{array}{l}2.554(1.069- \\
6.101)\end{array}$ & $\begin{array}{l}1.79(0.551- \\
5.820)\end{array}$ \\
\hline & No & $6(12.8)$ & 213(27.2) & 1.00 & \\
\hline \multirow[t]{2}{*}{ Availability of beddings at a MWH } & Yes & $34(72.3)$ & $415(53)$ & $\begin{array}{l}2.319(1.205- \\
4.62)\end{array}$ & $\begin{array}{l}5.35(2.21- \\
13)^{\star \star \star}\end{array}$ \\
\hline & No & $13(27.7)$ & $368(47)$ & 1.00 & \\
\hline \multirow[t]{2}{*}{$\begin{array}{l}\text { Availability of cooking facilities at } \\
\text { a MWH }\end{array}$} & Yes & $31(66)$ & 433(55.3) & $\begin{array}{l}1.566(0.843- \\
2.91)\end{array}$ & $\begin{array}{l}4.04(1.4- \\
12.1)^{\star}\end{array}$ \\
\hline & No & 16(34) & $350(44.7)$ & 1 & \\
\hline \multirow[t]{2}{*}{ Effect of peers } & Yes & 14(29.8) & 421(53.8) & 1.00 & \\
\hline & No & $33(70.2)$ & $362(46.2)$ & $\begin{array}{l}2.741(1.444- \\
5.203)\end{array}$ & $\begin{array}{l}2.7(1.204- \\
6.011)^{*}\end{array}$ \\
\hline
\end{tabular}

${ }^{*} p$-value $<0.05,{ }^{* * *} p$-value $<0.001,1=$ reference 


\begin{tabular}{|c|c|c|c|c|c|}
\hline \multirow[t]{3}{*}{ Variables } & & \multicolumn{2}{|c|}{$\begin{array}{l}\text { WTP for the nutrition } \\
\text { service }\end{array}$} & \multicolumn{2}{|l|}{ OR and $95 \% \mathrm{Cl}$} \\
\hline & & $<10$ ETB & $>=10 \mathrm{ETB}$ & $\operatorname{COR}(95 \% \mathrm{Cl})$ & $\operatorname{AOR}(95 \% \mathrm{Cl})$ \\
\hline & & $\begin{array}{l}n= \\
47(\%)\end{array}$ & $\begin{array}{l}n= \\
783(\%)\end{array}$ & & \\
\hline \multirow[t]{2}{*}{ Affordability } & Yes & $29(61.7)$ & $287(36.7)$ & $\begin{array}{l}2.784(1.519- \\
5.103)\end{array}$ & $\begin{array}{l}3.61(0.748- \\
17.382)\end{array}$ \\
\hline & No & 18(38.3) & $496(63.3)$ & 1.00 & \\
\hline \multirow[t]{2}{*}{ Service quality } & Yes & $45(95.7)$ & $694(88.6)$ & $\begin{array}{l}2.885(0.688- \\
12.1)\end{array}$ & $\begin{array}{l}1.1(0.19- \\
6.112)\end{array}$ \\
\hline & No & $2(4.3)$ & $89(11.4)$ & 1.00 & \\
\hline \multirow{2}{*}{$\begin{array}{l}\text { Perceiving as it is the government's } \\
\text { responsibility }\end{array}$} & Yes & $17(36.2)$ & $464(59.3)$ & 1.00 & \\
\hline & No & $30(83)$ & $319(40.7)$ & $\begin{array}{l}2.567(1.392- \\
4.733)\end{array}$ & $\begin{array}{l}3.6(1.7- \\
7.95) \star \star \star\end{array}$ \\
\hline \multirow[t]{2}{*}{$\begin{array}{l}\text { Availability of electric power at the } \\
\text { MWH }\end{array}$} & Yes & $45(95.7)$ & $667(85.2)$ & $\begin{array}{l}3.913(0.936- \\
16.35)\end{array}$ & $\begin{array}{l}3.61(0.748- \\
17.382)\end{array}$ \\
\hline & No & $2(4.3)$ & $116(14.8)$ & 1.00 & \\
\hline \multirow[t]{2}{*}{ Availability of kitchen at a MWH } & Yes & $41(87.2)$ & $563(71.9)$ & $\begin{array}{l}2.67(1.118- \\
6.378)\end{array}$ & $\begin{array}{l}1.25(0.406- \\
3.822)\end{array}$ \\
\hline & No & $6(12.8)$ & $220(28.1)$ & 1.00 & \\
\hline \multirow[t]{2}{*}{$\begin{array}{l}\text { Availability of adequate firewood at } \\
\text { a MWH }\end{array}$} & Yes & $39(83)$ & $516(65.9)$ & $\begin{array}{l}2.523(1.162- \\
5.475)\end{array}$ & $\begin{array}{l}2.52(0.933- \\
6.78)\end{array}$ \\
\hline & No & $8(17)$ & $267(34.1)$ & 1.00 & \\
\hline
\end{tabular}

\section{Discussion}

The maximum willingness to pay of households for the nutrition service provided to pregnant women at a MWH was measured using double bounded dichotomous contingent valuation method. The estimated (median) maximum WTP per household was found to be 15 ETB ( US\$ 0.55) per year with a minimum of 5 ETB and maximum of 500 ETB. The figure is higher than the price that the government wants to be paid by the households. On the other hand, the nutrition service program that provided nutrition services to pregnant women at a MWH suffers from shortage of revenue. This study shows that households are willing to pay for the nutrition services, and there is a room for the government to increase the fee charged. 
Older household heads were found to have higher willingness to pay for the service than their younger counterparts. This finding is similar with the study conducted in other areas of the countries $(6,19)$. One possible explanation is that since older female household heads are more likely to give more birth than younger ones and as most of them are living in rural areas, they might have experienced the nutrition service delivery at health facilities which are mostly located in towns. Similarly, in line with the findings of study conducted in other countries $(6,21)$, it is also found that respondents who were ever married were about 3.5 times more likely to be willing to pay for service than those who were never married. This could also be explained by the maternity experience of married women; i.e., married women are more likely to have previous utilization of nutrition service at $\mathrm{MWH}$ and see its benefit than those who were never married.

It is also noted that respondents who were college graduates and above have $65.4 \%$ less maximum willingness to pay than respondents who were illiterate. This finding is in line with the study conducted in other parts of Africa and Ethiopia (20). The possible reason might be due to high risk perception among less educated respondents on maternity care services. The perception of educated people on the quality of such services provided to the mass might also influence their willingness to pay.

Income of the respondent was found to be important determinant of WTP for the nutrition service at $\mathrm{MWH}$. Comparison is made between two groups of respondents with median monthly income of $100 \mathrm{ETB}$ and 1000 ETB. It was found that those with median monthly income of 1000 ETB were almost three times more likely to be willing to pay above the currently paid price compared to those who had median monthly income of 100ETB. This is in line with economic theory in that the higher the income; the more people are willing to pay for normal goods. It is also consistent with empirical from china and some other parts of Africa(20). Respondents who were closer (at less than $5 \mathrm{~km}$ ) to health facility were 3.6 times more likely to have WTP above the currently paid price than who were far (at greater than $5 \mathrm{~km}$ ) from the health facility. This may imply that those households who are distant from the health facilities seem to have less awareness on the importance of the service. The finding is in line with the study conducted at other parts African countries including Ethiopia $(22,23)$.

Respondents' perception about the quality of nutrition service (such as food, bed, and cooking facilities) at MWH is also affects the WTP of the households. This study shows that those households who believe that the there is enough food, bed, and cooking facilities at the $\mathrm{MWH}$ are more likely to be willing to pay above the currently paid price than others. This is also consistent with the finding of the study conducted in some parts of Africa (24).

Awareness on the ownership of the service/ program is found to have significant impact on WTP for nutrition service at $\mathrm{MWH}$ as respondents who believed that providing nutrition service to pregnant at MWH is government's responsibility were more likely to have WTP above the currently paid price than who had higher perceived government's responsibility counterparts $(A O R=3.6,95 \% \mathrm{Cl}=1.7-7.95)$. This is consistent with the study conducted on WTP and WTJ for newly proposed SHI in Ethiopia(15). The 
possible explanation might be due to the respondents' higher perception towards the maternal care service as it was totally an exempted service.

\section{Limitation of the study}

This is study is based on the respondents' stated preferences to the services which does not mean the households are committed

\section{Conclusion}

The study revealed the possibility of enhancing the revenue needed for the sustainability of nutrition service given to pregnant women at MWH as the average MWTP for the service is higher than the currently applied membership fee. Most households are willing to pay for the service though their MWTP varies. Demographic, socioeconomic, and institution specific factors affect households MWTP. Perception toward the quality of the service also affects the WTP for the service. .

\section{Recommendations}

It is evident from the discussion that there is a possibility of raising the membership fee. Thus, Federal ministry of health and policy makers should consider revising the fee so as to sustain the service provision and promote as well strengthen its functioning at all level of the health facility. Health facilities governing bodies should ensure availability of food items, cooking utensils and enough beds at a MWH as these affects households WTP. Furthermore, health extension workers and, community leaders, should mobilize communities in order to strengthen the communities' ownership by engaging in awareness creation activities.

\section{Abbreviations}

AOR: Adjusted Odd Ratio, DBDC: Double Bounded Dichotomous, CVM: Contingent Valuation Method, ETB: Ethiopian Birr, FMOH: Federal Ministry of Health, HC: Health Center, HDA: Health Development Army, HEW: Health Extension Workers, HF: Health Facility, HH: Household, JU: Jimma University, MNCH: Maternal Neonatal and child health services, MWH: Maternity Waiting Home, NGO: Non-governmental Organization, OR: Odd Ratio, SD: Standard Deviation, SMAGs: Safe Motherhood Action Groups, SPSS: Statistical Package for the Social Sciences, USD: United States Dollar, WHO: World Health Organisation, WTP: Willingness to Pay

\section{Declarations}

\section{Ethical approval}

The study was approved by Jimma University ethical review board. Permission to collect data was obtained from east Wollega zone health administration office. 


\section{Consent for publication}

Not applicable for this research

\section{Availability of data and materials}

The datasets used and/or analyzed during the current study are available from the corresponding author on reasonable request.

\section{Conflicts of interest}

The authors declare that they have no conflicts of interest.

\section{Funding}

Not applicable

\section{Consent}

A free informed consent written or verbal was obtained from each individual participant at the start of the study.

\section{Author's contribution}

Adisu Ewunetu participated and conceptualized the study, collected the data, led the analysis, and wrote the text of the paper, Teferi Daba and Gebeyehu Jeldu advised on the conceptualization of the study, analysis of the data, and presentation of the results. They also, reviewed, and edited the manuscript. All authors read and approved the final version of the manuscript.

\section{Acknowledgments}

We wish to acknowledge all those who agreed to participate in this study and the assistance provided by the staff of College of Public health at the University of Jimma. This study was benefited from MSc student thesis grant of Jimma University, Ethiopia.

\section{References}

1. Angore BN, Tufa EG, Bisetegen FS. Determinants of postnatal care utilization in urban community among women in Debre Birhan Town, Northern Shewa, Ethiopia. J Health Popul Nutr. 2018;37(1):10.

2. Pell C, Meñaca A, Were F, Afrah NA, Chatio S, Manda-Taylor L, et al. Factors affecting antenatal care attendance: results from qualitative studies in Ghana, Kenya and Malawi. PloS One. 2013;8(1):e53747.

3. Stekelenburg J, van Lonkhuijzen L, Spaans W Van. Roosmalen Jo. Maternity waiting homes in rural districts in Africa; A cornerstone of safe motherhood? Curr WOMENS Health Rev. 2006;2(4):235. 
4. Gaym A, Pearson L, Soe KW. Maternity waiting homes in Ethiopia-three decades experience. Ethiop Med J. 2012;50(3):209-19.

5. van Lonkhuijzen L, Stekelenburg J, van Roosmalen J. Maternity waiting facilities for improving maternal and neonatal outcome in low-resource countries. Cochrane Database Syst Rev. 2012;(10).

6. Organization WH. Maternity waiting homes: a review of experiences. Geneva: World Health Organization; 1996.

7. Control C, for D, Prevention. A guide to conducting household surveys for Water Safety Plans. Atlanta US Dep Health Hum Serv; 2008.

8. Sakai E, Uchida Y. A study on the use of 'contingent valuation'as a method for economic evaluation of the environment. Ritsumeikan J Asia Pac Stud. 2013;32.

9. Aizuddin AN, Sulong S, Aljunid SM. Factors influencing willingness to pay for healthcare. In: BMC Public Health. Springer; 2012. p. A37.

10. Aleme A, Girma E, Fentahun N. Willingness to pay for insecticide-treated nets in Berehet District, Amhara Region, Northern Ethiopia: implication of social marketing. Ethiop J Health Sci. 2014;24(1):75-84.

11. Scott NA, Vian T, Kaiser JL, Ngoma T, Mataka K, Henry EG, et al. listening to the community: Using formative research to strengthen maternity waiting homes in Zambia. PIOS One. 2018;13(3):e0194535.

12. Vian T, White EE, Biemba G, Mataka $K$, Scott N. Willingness to pay for a maternity waiting home stay in Zambia. J Midwifery Womens Health. 2017;62(2):155-62.

13. Unicef. Innovative approaches to maternal and newborn health. Compendium of case studies. NY UNICEF; 2013.

14. Agago TA, Woldie M, Ololo S. Willingness to join and pay for the newly proposed social health insurance among teachers in Wolaita Sodo town, South Ethiopia. Ethiop J Health Sci. 2014;24(3):195-202.

15. Sambo L, Chatora R, Goosen E. Tools for assessing the operationality of district health systems. Brazzaville World Health Organ Reg Off Afr; 2003.

16. Gyrd-Hansen D, Jensen ML, Kjaer T. Framing the willingness-to-pay question: impact on response patterns and mean willingness to pay. Health Econ. 2014;23(5):550-63.

17. Melka SG. HOUSEHOLDS' WILLINGNESS, TO PAY FOR ENVIRONMENTAL Health. Risk Reductions when there are Varying Degrees of Life Expectancy. Article. 2007;1(July):41-3.

18. Nguyen PH, Hoang MV, Hajeebhoy N, Tran LM, Le CH, Menon P, et al. Maternal willingness to pay for infant and young child nutrition counseling services in Vietnam. Glob Health Action. 2015;8(1):28001.

19. Lori JR, Wadsworth AC, Munro ML, Rominski S. Promoting access: the use of maternity waiting homes to achieve safe motherhood. Midwifery. 2013;29(10):1095-102. 
20. Adisu A, Aleme A, Girma E, Fentahun N. ORIGINAL ARTICLE WILLINGNESS TO PAY FOR INSECTICIDE-TREATED. NETS IN BEREHET DISTRICT, AMHARA REGION, NORTHERN ETHIOPIA : IMPLICATION OF SOCIAL MARKETING. Ethiop J Health Sci. 2014;24:78-80.

21. Vermeiden T, Braat F, Medhin G, Gaym A, van den Akker T, Stekelenburg J. Factors associated with intended use of a maternity waiting home in Southern Ethiopia: a community-based cross-sectional study. BMC Pregnancy Childbirth. 2018;18(1):38.

22. Hou Z, Chang J, Yue D, Fang H, Meng Q, Zhang Y. Determinants of willingness to pay for self-paid vaccines in China. Vaccine. 2014;32(35):4471-7.

23. Endalew GB, Gebretsadik LA, Gizaw AT. Intention to use Maternity Waiting Home among Pregnant Women in Jimma District, Southwest Ethiopia. Glob J Med Res. 2017.

24. Roeland L, Willem C. Delay in safe motherhood Chap. 3 Maternity waiting facilities for improving maternal and neonatal outcome in low- resource countries. Delay Safe Mother. 2011;(3):30-2.

\section{Figures}

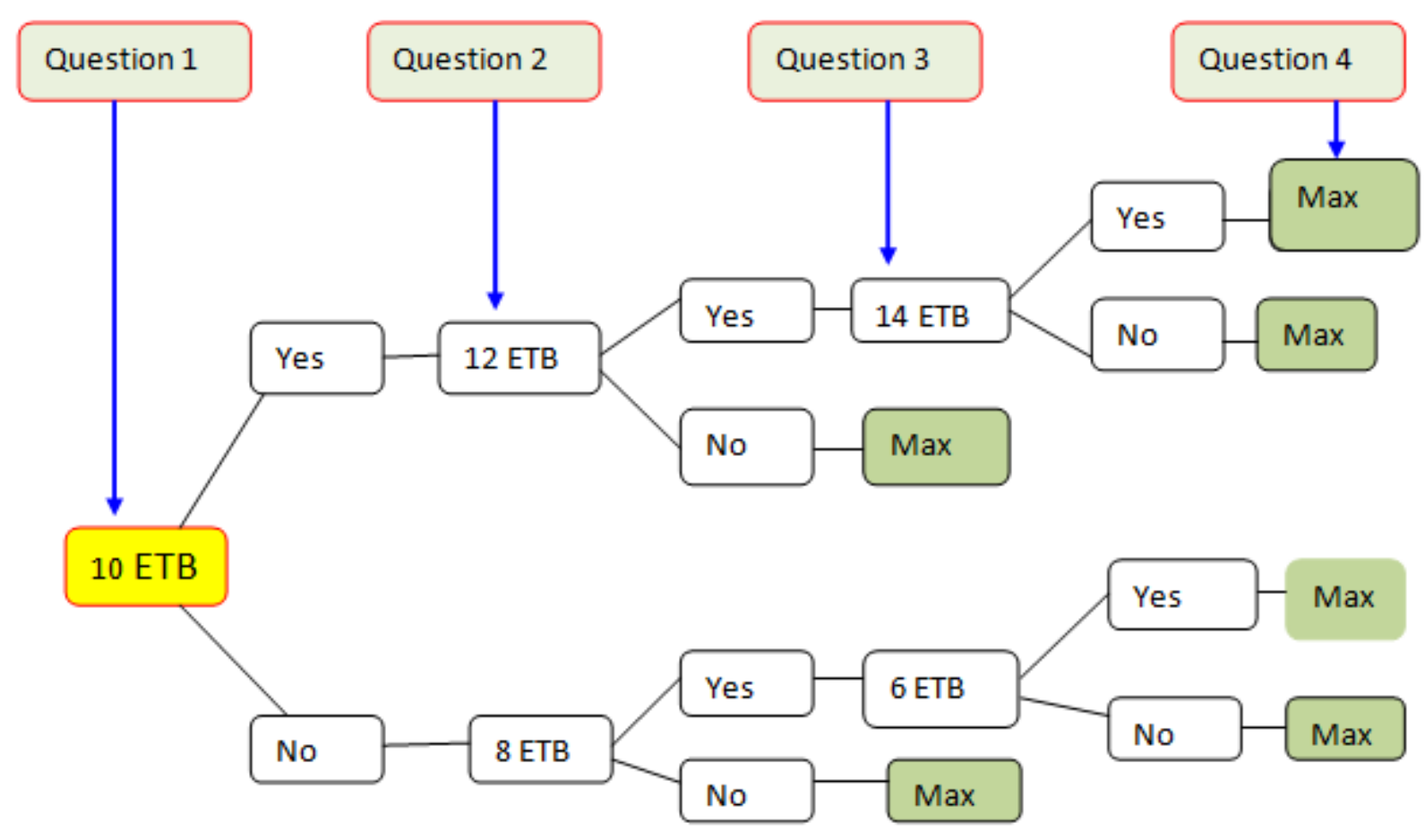

Figure 1

Sequence of willingness to pay questions depending on respondents' response to each price bid 


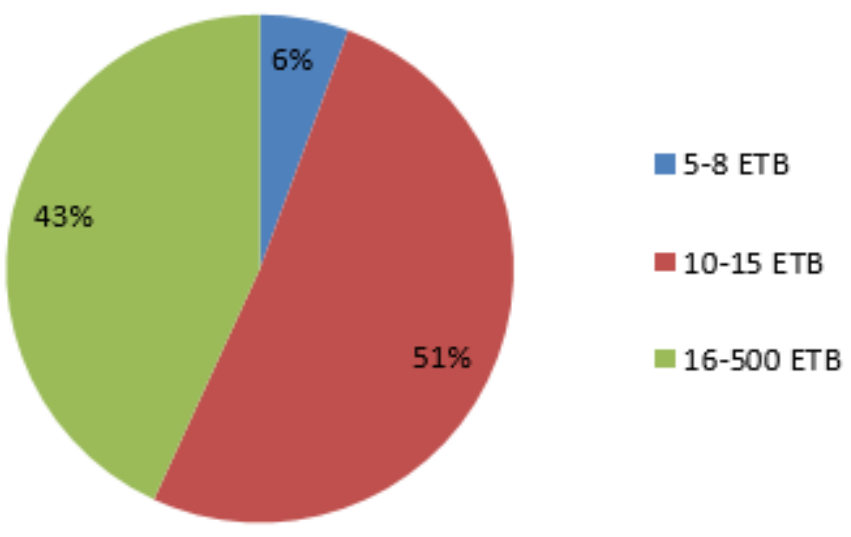

Figure 2

Percentage of respondents willing to pay a certain range for the nutrition service(Exchange rate: US\$1=27.471 ETB, source (18) 